\title{
Identification of alternatively spliced MsRan transcripts involved in low temperature response in Musa spp.
}

\author{
Y.L. ZHANG ${ }^{1}$, Z.Z. FANG ${ }^{2}$, and Z.X. LAI ${ }^{1 *}$ \\ Institute of Horticultural Biotechnology, Fujian Agriculture and Forestry University, \\ Fuzhou, Fujian 350002, P.R. China ${ }^{1}$ \\ Fruit Research Institute, Fujian Academy of Agricultural Sciences, Fuzhou, Fujian 350013, P.R.China ${ }^{2}$
}

\begin{abstract}
Ran is involved in response to external stimuli. In this study, six MsRan gene cDNA sequences were isolated from wild banana (Musa spp. AB group) from Sanming City, China. Sequence analysis reveals that MsRan3A, MsRan3A-1a, and MsRan3C contained Ran protein domains including a GTP hydrolysis domain, a RanGAP-binding domain, and an acidic tail, whereas two G boxes (G4 and G5) were absent in MsRan3A-6a. The physicochemical property of MsRan3A, MsRan3A-1a, MsRan3A-6a, and MsRan3C appeared to differ significantly. Real time quantitative PCR (qPCR) analysis indicates that MsRan 3A-1, MsRan3A-5, MsRan3A-6, MsRan 3A-6a, and MsRan3C-1 were expressed in roots, leaves, peduncles, bracts, flowers, peels, and pulp of the wild banana. MsRan $3 A-1 a$ was expressed at extremely low levels in these tissues and was undetectable by qPCR. The MsRan genes were found to be involved in responses to a low temperature stress but with different response patterns. Furthermore, salicylic acid significantly enhanced MsRan gene expressions suggesting the involvement of these genes in salicylic acid signal transduction.
\end{abstract}

Additional keywords: gene expression, salicylic acid, wild banana.

\section{Introduction}

Banana (Musa spp.), an important food staple and income-generating fruit crop in tropical and subtropical regions, is sensitive to biotic and abiotic stresses such as pests, drought, and low temperatures. In particular, a low temperature has a serious impact on banana yield and fruit quality (Yang et al. 2012). In a previous study, we identified several wild banana populations with cold resistance, including one from Sanming, Fujian Province, China (Lai et al. 2006, 2007). The identification of cold resistance related genes from cold resistant wild banana and the investigation of the underlying mechanisms are useful for genetic improvement and production of banana.

Ran, a Ras-related nuclear protein, belongs to a highly conserved small $\mathrm{G}$ protein family present in eukaryotic organisms. In mammals, Ran is involved in multiple cellular processes (Ciciarello et al. 2007, Clarke and Zhang 2008, Dallol et al. 2009). It also participates in cellular signal transduction (Liu et al. 2010). Arabidopsis contains four Ran genes (Vernoud et al. 2003). Genomic analysis revealed the presence of nine Ran genes in the genome of Musa acuminata (D'Hont et al. 2012, Zhang et al. 2015b). Studies have revealed that plant Ran proteins share a high sequence similarity with their counterparts from yeast and animals and function similarly (Ach and Gruissem 1994, Wang et al. 2004, 2006, Yano et al. 2006, Lee et al. 2008, Zang et al. 2010, Lü et al. 2011). Plant Ran proteins are expressed in various tissues, especially in meristematic tissue (Ach and Gruissem 1994, Haizel et al. 1997, Wang et al. 2006, Lü et al. 2011). Zang et al. (2010) have demonstrated that a reduced expression of OsRan2 causes developmental

Submitted 20 September 2015, last revision 28 June 2016, accepted 12 July 2016.

Abbreviations: AUAP - abridged universal amplification primer; BA - 6-benzyladenine; MS - Murashige and Skoog; NAA - naphthalene acetic acid; ORF - open reading frame; pI-isoelectric point; qPCR - quantitative PCR; RACE - rapid amplification of cDNA ends; SA - salicylic acid; UTR - untranslated region.

Acknowledgments: This work was funded by the earmarked funds for Modern Agro-industry Technology Research System of China (CARS-32-11) and by the Fujian Provincial Science and Technology Platform Construction Project (2008N2001). All authors contributed equally to this work.

* Corresponding author; e-mail: laizx01@163.com 
abnormalities in rice, and Chen et al. (2011) have shown that development in OsRAN2-knockdown rice plants is delayed, and spindle organization is aberrant. These results indicate that Ran has a fundamental role in plant development.

According to several studies, Ran is also involved in responses to an external stimulus. For example, Ran protein expression is enhanced under heat stress (Ferreira et al. 2006, Xu and Huang 2008, 2010), and low temperatures stimulate Ran transcript accumulation as well (Chen et al. 2011, Paul and Kumar 2011). Miché et al. (2006) revealed that jasmonic acid, a plant hormone that participates in signaling multiple stresses, induces Ran protein expression in rice roots. Lee et al. (2008) determined that various light sources regulate expression of the Ran gene through phytochrome-mediated signaling pathways. An enhanced accumulation of the Ran protein has also been found in NaCl-treated Arabidopsis roots (Jiang et al. 2007). Two Ran GTPases were found to accumulate in roots of wild watermelon under water deficits. Lee et al. (2008) reported that various light sources regulate Ran gene expression through

\section{Materials and methods}

Plants and treatments: Wild banana (Musa spp. AB group) from Sanming city was grown in our germplasm repository (the Fujian Agriculture and Forestry University, Fuzhou, Fujian Province, China). Suckers were collected, rinsed, and treated as described by Zhang et al. (2006). The explants were inoculated into a halfstrength Murashige and Skoog (MS) medium ( $\mathrm{pH} 5.8$ ) supplemented with $30 \mathrm{~g} \mathrm{dm}^{-3}$ sucrose, $6.0 \mathrm{~g} \mathrm{dm}^{-3}$ agar, $3.0 \mathrm{mg} \mathrm{dm}$ 6-benzyladenine (BA), $0.1 \mathrm{mg} \mathrm{dm}^{-3}$ naphthaleneacetic acid (NAA), and $0.5 \mathrm{~g} \mathrm{dm}^{-3}$ active carbon and cultivated at $28 \pm 1{ }^{\circ} \mathrm{C}$ under the dark. After budding, the cultures were transferred and maintained at a temperature of $28 \pm 1{ }^{\circ} \mathrm{C}$, a 12 -h photoperiod, and an irradiance of $200 \mu \mathrm{mol} \mathrm{m} \mathrm{m}^{-2} \mathrm{~s}^{-1}$. For propagation, the established cultures were transferred to an MS medium supplemented with $30 \mathrm{~g} \mathrm{dm}^{-3}$ sucrose, $6.0 \mathrm{~g} \mathrm{dm}^{-3}$ agar, $1.0 \mathrm{mg} \mathrm{dm}^{-3} 6-\mathrm{BA}$, and $0.1 \mathrm{mg} \mathrm{dm}^{-3} \mathrm{NAA}$ (pH 5.8). For cold and SA treatments, shoot cultures subcultured on the propagation medium for $20 \mathrm{~d}$ were used. For tissuespecific expression analysis, we collected roots, leaves, peduncles, bracts, flowers, peels, and pulp from adult plants with fruits at $60 \%$ maturity (Fig. 1 Suppl.). To examine the responses of wild banana to low temperature stresses, shoot cultures were exposed to various temperatures $\left(0,4,8,13,20\right.$, and $\left.28^{\circ} \mathrm{C}\right)$ for $36 \mathrm{~h}$ and to $8{ }^{\circ} \mathrm{C}$ for various time periods $(0,1,4,8,12$, and $24 \mathrm{~h})$. Salicylic acid treatment was carried out by spraying shoot cultures with distilled water containing 0 (control) or $0.5 \mathrm{mM}$ SA. Both control and SA-treated shoot cultures were subsequently incubated under $8{ }^{\circ} \mathrm{C}$. Samples were taken at $1,4,8,12$, and $24 \mathrm{~h}$. The tissues and treated phytochrome-mediated signaling pathways. Wang et al. (2006) demonstrated that overexpression of TaRAN1 renders Arabidopsis hypersensitive to auxin. Zang et al. (2010) has reported similar results in rice with transgenic plants overexpressing OsRAN2 exhibiting an enhanced sensitivity to salinity, osmotic stress, and abscisic acid. Chen et al. (2011) further indicated that OsRAN2overexpressing transgenic rice displays an enhanced cold tolerance. These authors suggested that OsRAN2 maintains cell division by promoting the normal export of intranuclear tubulin at the end of mitosis and regulates cold resistance in rice. The results of these studies imply that Ran genes play a crucial role in plant stress response.

Fifteen DNA sequences and six cDNA sequences of Ran genes have been isolated from wild banana previously (Zhang et al. 2014, 2015a). In this study, we isolated MsRan genes and alternative spliced transcripts from the wild banana. We then assessed their tissuespecific expression profiles as well as their expressions under low temperature stresses and salicylic acid (SA) treatment.

shoot cultures were harvested and immediately frozen in liquid nitrogen and stored at $-80{ }^{\circ} \mathrm{C}$ until further use.

Cloning MsRan genes: The total RNA was extracted from the frozen samples using an EZNA plant RNA kit (Omega Bio-Tek, Norcross, GA, USA) followed by treatment with DNase I (Takara Biotechnology, Dalian, China) to remove genomic DNA. The cDNA was synthesized with a RevertAid ${ }^{\mathrm{TM}}$ first-strand cDNA synthesis kit (Fermentas, Thermo Fisher Scientific, Waltham, MA, USA). MsRan gene fragments were amplified using three primer pairs (RanF-4/RanR-4, RanF-5/RanR-5, and RanF-8/RanR-8) designed according to Ran gene sequences from the Musa acuminata genome (http://banana-genome.cirad.fr/) and from the National Center for Biotechnology Information (NCBI) database. To clone the full-length cDNA sequence of MsRan genes, we carried out a rapid amplification of cDNA ends (RACE) using primers designed according to the obtained MsRan gene fragments. The 3'-RACE was performed using a firststrand cDNA synthesis kit (Fermentas) with an oligo-dT adapter primer (AP). The cDNA was then subjected to nested PCR using gene-specific primers (Ran3'RACE-1, Ran3'RACE-2, and Ran3'RACE-3) and a universal amplification primer (AUAP). In the case of $5^{\prime}$-RACE, the first-strand cDNA was synthesized using an oligodT primer and SuperScript ${ }^{T M}$ III (Invitrogen, Carlsbad, CA, USA), and the product was purified using a MiniBEST DNA fragment purification kit (Takara). A homopolymeric tail was then added to the cDNA 3 '-end using 
terminal deoxynucleotidyl transferase (Takara) and dCTP. Nested PCR was carried out with two upstream primers (AP3 and AUAP) and three gene-specific downstream primers (Ran5'RACE-1, Ran5'RACE-2, and Ran5'RACE-3) to amplify the 5'-end of MsRan genes. The full-length MsRan was amplified by RT-PCR using primers designed according to $5^{\prime}$ - and $3^{\prime}$-untranslated region (UTR) sequences. After resolving the PCR products on a $1 \%(\mathrm{~m} / \mathrm{v})$ agarose gel, the bands were excised, purified, subcloned into a pMD18-T vector (Takara), and sequenced. All primers used for isolating MsRan genes are listed in Table 1 Suppl.

Bioinformatics analysis: Nucleotide and deduced amino acid sequences and amino acid sequence alignments were analyzed by the DNAMAN software. The open reading frames (ORFs) of MsRan cDNAs were determined using ORF Finder (www.ncbi.nlm.nih.gov/gorf/) and translated into the corresponding amino acid sequence. Homology comparisons were conducted using the $B L A S T$ program at the NCBI (http://www.ncbi.nlm.nih.gov/blast). The theoretical isoelectric point (pI) and mass values of mature peptides were calculated using the ProtParam tool (http://web.expasy.org/protparam). A phylogenetic tree was constructed by the neighbor-joining method with 1000 bootstrap replicates in MEGA 5 .

Real-time quantitative PCR: The total RNA (500 ng) was transcribed into cDNA with random primers and an oligodT primer using a PrimeScript $R T$ reagent kit (Takara). Real time quatitative PCRs (qPCRs) were performed on a Lightcycler 480 system (Roche Applied Science, Basel, Switzerland) as described by Fang et al. (2016). Reactions were run in three biological replicates and three technical replicates using $18 \mathrm{~S}$ rRNA as an internal control. Analyses of expression data were performed with GeNorm v. 3.5 (Vandesompele et al. 2002). The specificity of the products from the real time qPCR experiments were confirmed by melting curve analysis and sequencing. All primers are listed in Table 2 Suppl.

\section{Results}

Six MsRan cDNAs were isolated from wild banana by real time PCR coupled with 5'- and 3'-RACE using primers listed in Table 1 Suppl. Sequence analysis indicates that MsRan3A-1, MsRan3A-5, MsRan3A-6, and MsRan3C-1 contained a 663-bp ORF, whereas MsRan3A-1 a and MsRan3A-6a contained ORFs of 585 and $483 \mathrm{bp}$, respectively. The comparison of nucleotide sequences demonstrates that they were highly homologous. The sequences of MsRan3A-1 and MsRan3A-1a were identical and the sequences of MsRan3A-5, MsRan3A-6, and MsRan3A-6a were similar to one another. The genomic sequence encoding
MsRan3A-1 and MsRan3A-1a (GenBank accession No. KC898288) and the ones encoding MsRan3A-5, MsRan3A-6, and MsRan3A-6a (GenBank acc. No. KC898291) have been previously isolated (Zhang et al. 2014). The comparative structural analysis of $M s$ Ran $3 A-1$ and MsRan3A-1a reveal that the coding region of MsRan3A-1a lacked a 78-bp exon (Fig. 1). The comparison of the structures of MsRan3A-5, MsRan3A-6, and MsRan3A-6a indicates that the coding region of MsRan3A-6a lacked a 180-bp exon and that the $3^{\prime}$-UTR of MsRan3A-5 lacked a 75-bp sequence (Fig. 1).

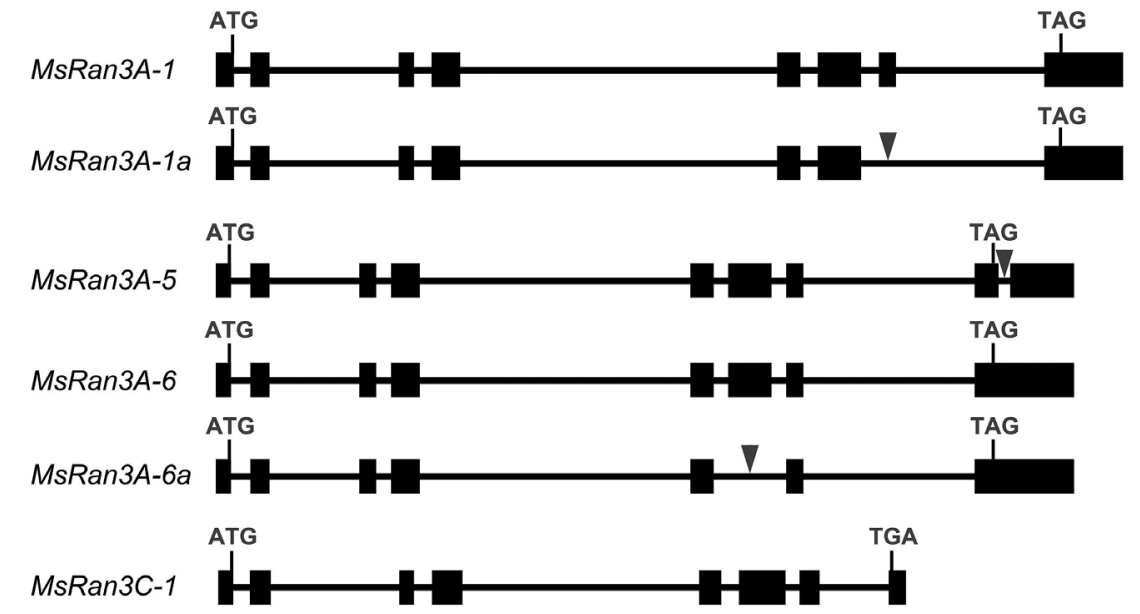

Fig. 1. Schematic representations indicate splicing patterns of MsRan gene transcripts. Bold lines indicate introns, black boxes indicate exons, ATGs indicate start codons, TAGs indicate termination codons, arrows indicate locations where sequence deletions exist. 


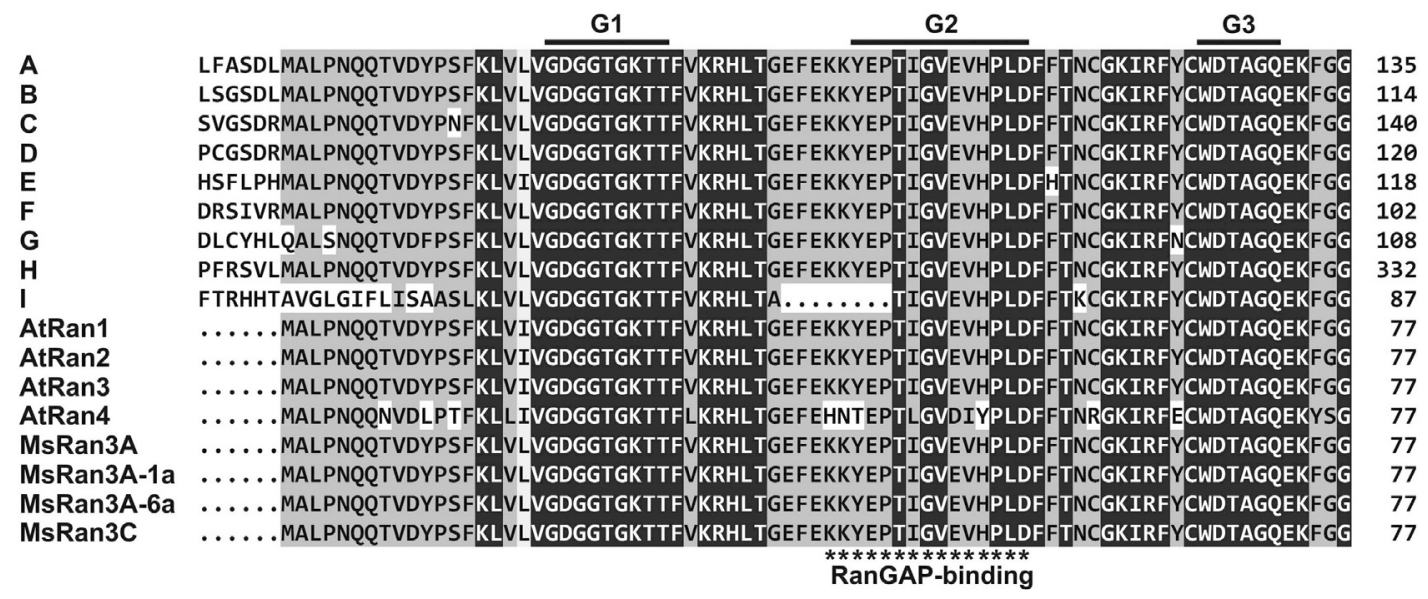

A
B
C
D
E
F
G
H
I
AtRan1
AtRan2
AtRan3
AtRan4
MsRan3A
MsRan3A-1a
MsRan3A-6a
MsRan3C

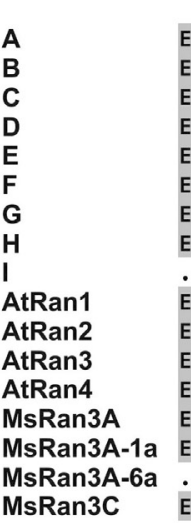

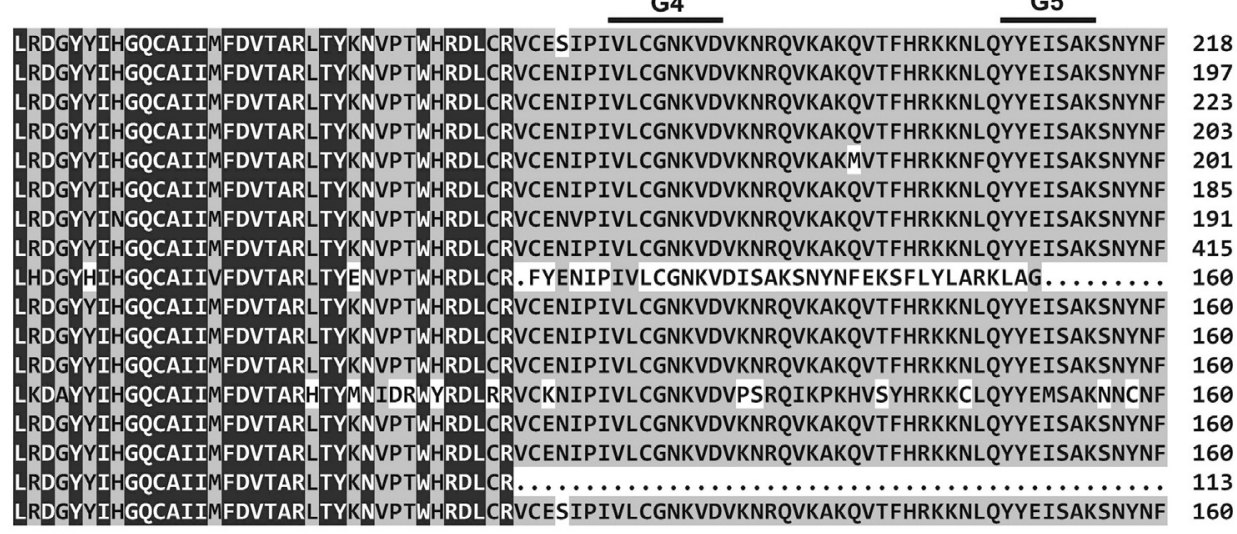

\section{Acidic tail}

EKPFLYLARKLAGDPNLHFVESPALAPPEVQIDLAAQQQH $\ldots \ldots \ldots \ldots \ldots \ldots$ EAELAAAAAQPLPDDDDDVFD . . . . 279 EKPFLYLARKLAGDPNLHFVESPALAPPEVOIDLAAOOOH $\ldots \ldots \ldots \ldots \ldots \ldots$ EAELAAAAAOPLPDDDDDVFD $\ldots \ldots \ldots 258$ ERPFLYLARKLAGDPNLHFVESPALAPPEVQIDLAAQQQH $\ldots \ldots \ldots \ldots \ldots \ldots$ EAELAAAAAQPLPDDDDDIFD $\ldots \ldots \ldots .284$ EKPFLYLARKLAGDPNLHFVESPALAPPEVQIDLAAQQQH. $\ldots \ldots \ldots \ldots \ldots \ldots$ EAELAAAAAQPLPDDDDDVFD $\ldots \ldots \ldots \ldots$

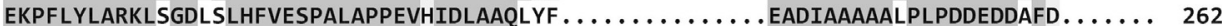
EKPFLYLARKLAGDPNLHFVESPALAPPEVQIDLAAQQOH $\ldots \ldots \ldots \ldots \ldots \ldots$ EAELAAAAAQPLPDDDDDVFD $\ldots \ldots \ldots 246$ EKPFLYLARKLAGDQNLHFVESPALAPPEVQIDLAAQQQH $\ldots \ldots \ldots \ldots \ldots \ldots$ EAELAAAAAQPLPDDDDDLFE $\ldots \ldots \ldots .252$ EKPFLYLARKLAGDQNLHFVESPALAPPEVQIDLVAQQQH $\ldots \ldots \ldots \ldots \ldots \ldots$ EAELAAAAAQPLPDDDDDLFI $\ldots \ldots \ldots$. $\ldots \ldots \ldots \ldots$. . . . . .

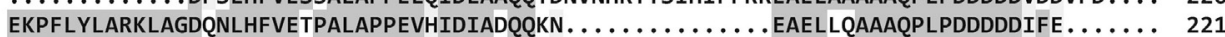
EKPFLYLARKLAGDQNLHFVESPALAPPEVHLDIAAQQQN $\ldots \ldots \ldots \ldots \ldots \ldots$ EADLAAAAAQPLPDDDDDAFE $\ldots \ldots \ldots$

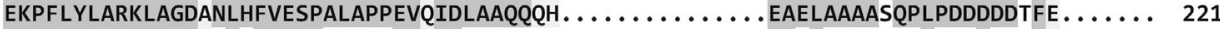
EKPFLYLARRIAGDAKLSFVESPEAQIDNLDVESLQLLTVEAG. . . . . . . TQPLLMTRISFEF . . NTLSIE . . . . . 222 EKPFLYLARKLAGDPNLHFVESPALAPPEVQIDLAAQQQH $\ldots \ldots \ldots \ldots \ldots \ldots$ EAELAAAAAQPLPDDDDDVFD $\ldots \ldots \ldots .221$

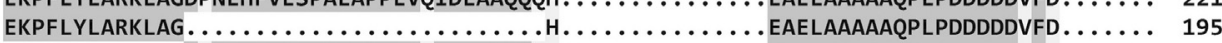

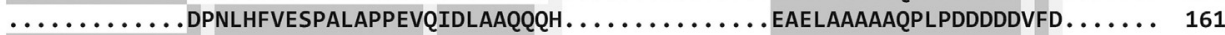

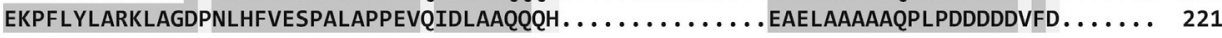

Fig. 2. Multiple alignments of Ran sequences from banana and Arabidopsis. A-H - predicted Ran proteins from the banana genome encoded by $A$ : Achr1T05300, $B$ : Achr1T11790, C: Achr1T14580, D: Achr4T00780, E: Achr5T06130, F: Achr5T09850, $G$ : Achr6T01500, $H$ : AchrUn_randomT07030, I: GSMUA AchrUn randomP07030. Conserved GTP binding and hydrolysis domains (G1-G5) are indicated by bold lines. An effector-binding domain (RanGAP-binding) and an acidic C-terminal region (acidic tail) are indicated with asterisks and triangles, respectively.

MsRan3A-1, MsRan3A-5, and MsRan3A-6 were found to encode a protein of 221 amino acids with a predicted molecular mass of $25.1 \mathrm{kDa}$ and a $\mathrm{pI}$ of 6.38. A protein encoded by $M s R a n 3 C-1$ was also found to comprise 221 amino acids with a predicted molecular mass of $25.0 \mathrm{kDa}$ and a pI of 6.38 . Sequence deletions in MsRan3A-1 $a$ and MsRan3A-6a were responsible for the absence of 26 and 60 amino acids in their deduced proteins, respectively. A predicted molecular mass and $\mathrm{pI}$ of MsRan3A-1a were $22.3 \mathrm{kDa}$ and 8.15 , respectively, whereas corresponding values in MsRan3A-6a were $18.1 \mathrm{kDa}$ and 4.88 . Analysis by BLAST reveals that predicted MsRan proteins shared a high similarity with Ran homologs from other plants. Multiple alignments with Ran homologs from Arabidopsis and M. acuminata indicate that MsRan3A, MsRan3A-1a, and MsRan3C 
contained several conserved motifs including $G$ boxes (G1 - G5), a RanGAP-binding domain and an acidic C-terminal region (Fig. 2). In MsRan3A-6a, however, G4 and G5 domains, known to be involved in GTP-binding and hydrolysis, were lacking. To study the relationships of predicted MsRan proteins and their orthologs in other species, we generated a phylogenetic tree of deduced amino acid sequences of the MsRans and 19 other Ran homologs. In the phylogenetic tree, the Ran sequences from banana, except for MsRan3A-1a and Achr5T06130, fell into the same clade and were closely related to AtRan3. This placement suggests that MsRan3A, MsRan3A-6a, MsRan3B, MsRan3C, and MsRan3D share a conserved role with Ran3 (Fig. 3).

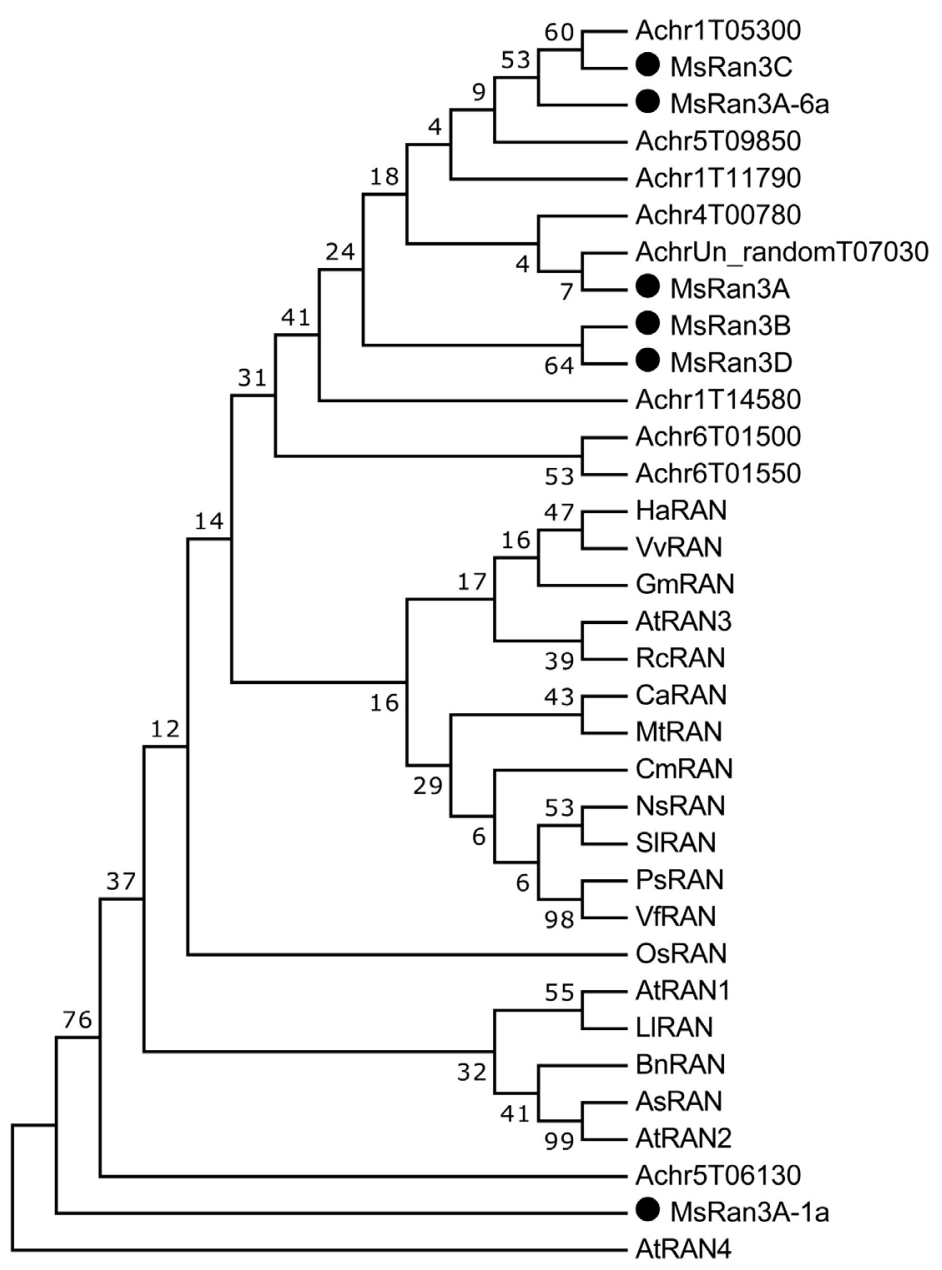

Fig. 3. A phylogenetic tree of deduced amino acid sequences of Ran proteins from Musa acuminata and other plant species. Phylogenetic and evolutionary analyses were performed using the neighbor-joining method by the MEGA 5 software. Additional sequences include Ran proteins from Allium sativum (AsRAN, ABD17865), Arabidopsis thaliana (AtRAN1, NP 197501, AtRAN2, NP_197502, AtRAN3, NP_200330), Brassica napus (BnRAN, ABD17866), Cicer arietinum (CaRan, NP_001265929), Cucurbita maxima (CmRAN, AEK84227), Glycine max (GmRan, XP_003522628), Helianthus annuus (HaRan, AF495716_1), Lepidium latifolium (LIRAN, AEK78856), Medicago truncatula (MtRĀN, ACJ83982), Musa acuminata (as described in Fig. 2), Nicotiana sylvestris (NsRan, NP_001289503), Oryza sativa (OsRAN, NP_001043550), Pisum sativum (PsRAN, ABM73376), Ricinus communis (RcRan, XP 002515555), Solanum lycopersicum (SIRĀN, NP 001234016), Vicia faba (VfRAN, P38548), and Vitis vinifera (VvRAN, XP_002284967).

Real time qPCR analysis was performed to assess the expression pattern of the MsRan genes in different wild banana tissues (Fig. 4). MsRan3A-1, MsRan3A-5, MsRan3A-6, MsRan3A-6a, and MsRan3C-1 were expressed in all tested tissues. MsRan3A-1, MsRan3A-5, and MsRan3C-1 were weakly expressed in roots, peduncles, bracts, and peels with the lowest expression in roots, and were highly expressed in leaves, flowers, and pulp. MsRan3A-6 and MsRan3A-6a had the highest expressions in leaves followed by peduncles and showed the lowest expression in bracts. Interestingly, only a small amount of MsRan3A-1a was detected in any tested tissue (Ct values were greater than 34).

To investigate the effects of low temperatures on MsRan gene expressions, we subjected in vitro seedlings of wild banana to various temperatures (Fig. 5). 
Expression of MsRan $3 A-1$ decreased slightly under $20^{\circ} \mathrm{C}$ treatment and increased to a higher level under $13{ }^{\circ} \mathrm{C}$ treatment. When exposed to a temperature of $8{ }^{\circ} \mathrm{C}$, MsRan3A-1 expression was reduced to the lowest level, at even lower temperatures $\left(4\right.$ and $0{ }^{\circ} \mathrm{C}$ ), however, its expression was enhanced. As temperatures were lowered from 28 to $13{ }^{\circ} \mathrm{C}$, expression of $M s$ Ran $3 C$ - 1 increased. Similar to MsRan3A-1, MsRan3C-1 showed the lowest expression under $8{ }^{\circ} \mathrm{C}$ with even lower temperatures enhancing its expression (Fig. 5). The lowest expressions of MsRan3A-5, MsRan3A-6, and MsRan3A-6a were detected during $20{ }^{\circ} \mathrm{C}$ treatment. Expressions of these genes gradually increased as temperature was lowered from 20 to $8{ }^{\circ} \mathrm{C}$, and the highest expressions were detected at $0{ }^{\circ} \mathrm{C}$.

We also performed time-course experiments involving $8{ }^{\circ} \mathrm{C}$ treatment. Expressions of MsRan3A-1, MsRan3A-5, MsRan3A-6, and MsRan3A-6a increased slightly from 0 to $4 \mathrm{~h}$, and after $8 \mathrm{~h}$ of treatment, their expressions rapidly decreased to their lowest levels and remained there (Fig. 6). Conversely, expression of MsRan 3C-1 was reduced after $1 \mathrm{~h}$ of treatment and then rose after $4 \mathrm{~h}$ to pre-treatment levels. Similar to other transcripts, MsRan 3C-1 was expressed at the lowest level after $8 \mathrm{~h}$ of treatment and remained at a low level thereafter (Fig. 6). These data suggest that MsRan genes are involved in a response to low temperature stress with various transcripts responding to low temperatures according to different patterns.

We also examined the effects of SA on expressions of MsRan genes under low temperature stress (Fig. 7). MsRan gene expressions were significantly enhanced after $1,8,12$, and $24 \mathrm{~h}$ of SA treatment at $8^{\circ} \mathrm{C}$. After $4 \mathrm{~h}$ of SA treatment, however, MsRan3A-1, MsRan3A-6, MsRan3A-6a, and MsRan3C-1 expressions were only slightly repressed, whereas $M s R a n 3 A-5$ expression was unaffected. These results imply that MsRan genes participate in SA signalling.

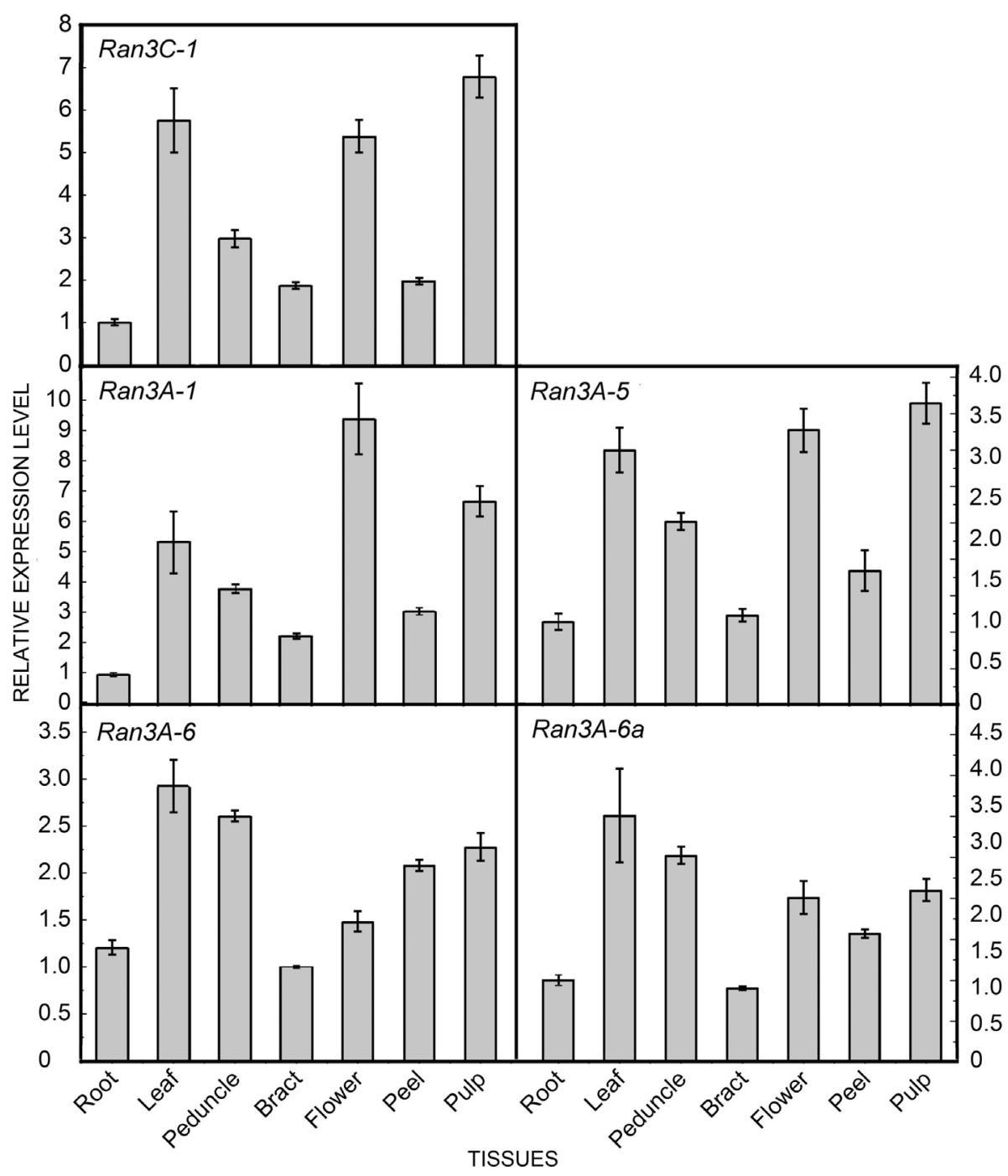

Fig. 4. Expression analysis of MsRan genes in various tissues of adult wild banana. The total RNA was extracted from various tissues and subjected to real time quantitative PCR analysis. All data were normalized to the expression of $18 \mathrm{~S}$ rRNA. Means \pm SEs, $n=3$. 


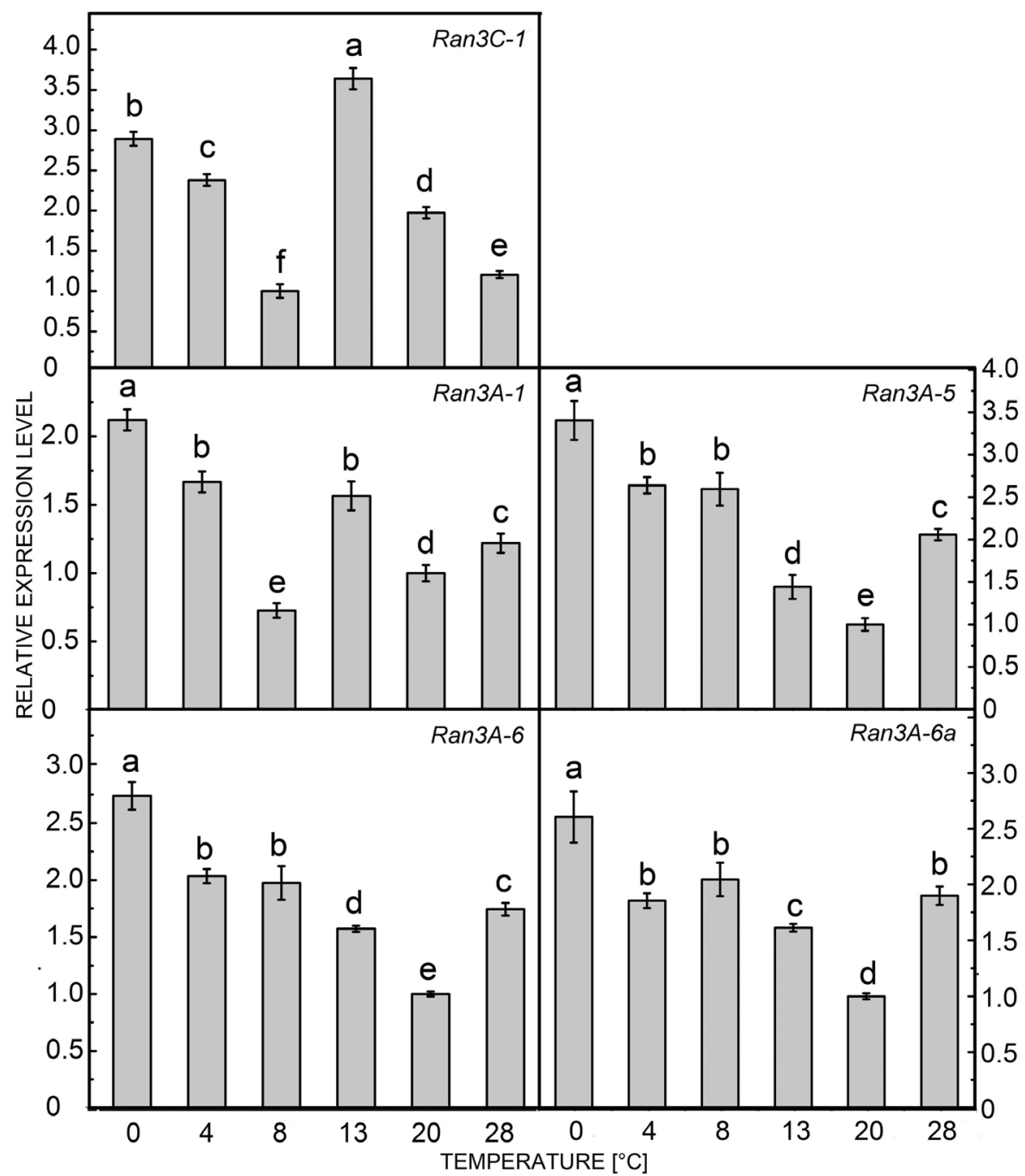

Fig. 5. Expression analysis of MsRan genes under low temperature stresses. The total RNA was extracted from shoot cultures treated by different temperatures and subjected to real time qPCR analysis. All data were normalized to the expression of 18S rRNA. Means \pm SEs, $n=3$. Significant differences were determined by one-way ANOVA $(P<0.05)$ and are indicated by different letters.

\section{Discussion}

Plant Ran proteins are abundantly expressed in meristematic tissue (Haizel et al. 1997, Lü et al. 2011). Fang et al. (2014) have demonstrated that DlRan transcripts are highly expressed during developmental stages when cells are actively proliferating. Wang et al. (2006) reported that TaRAN1-overexpressing Arabidopsis plants exhibit increased primordial meristems, tillering, apical dominance, and the number of rosette leaves and of cells in the root meristem zone. These studies suggest that Ran is also involved in regulation of cell division. Our results indicate that predicted MsRan proteins are highly similar to Ran proteins from other plants. MsRan transcripts were weakly expressed in old tissues and highly expressed in young ones. Furthermore, their expressions were significantly reduced after treatment at
$8{ }^{\circ} \mathrm{C}$ for $8 \mathrm{~h}$. It was reported that banana growth is arrested and injury occurs under this temperature (Yang et al. 2012). However, different transcripts showed varied expression patterns. The various MsRan genes may thus have divergent functions. Further investigation is needed to determine their exact function.

Alternative splicing is a post-transcriptional regulatory mechanism that plays important roles in regulation of gene expression (Lareau et al. 2004, Stamm et al. 2005). This is a powerful mechanism for regulation of plant stress response (Mastrangelo et al. 2012). Alternatively spliced Ran transcripts have rarely been identified. Fang et al. (2016) isolated an alternatively spliced DlRan transcript containing a premature terminator codon from somatic embryos of longan and 
proposed its involvement in regulation of the DlRan gene expression. In the present study, three alternatively spliced transcripts of MsRan were isolated from wild banana. Exon deletions were detected in the coding regions of MsRan $3 A-1 a$ and MsRan3A-6a. The predicted protein encoded by MsRan3A-1a contained all of the conserved motifs, whereas that of $M s \operatorname{Ran} 3 A-6 a$ lacked the G4 and G5 boxes, which are involved in GTPase hydrolysis. MsRan $3 A-1 a$ was not detected in any tested sample, whereas $M s \operatorname{Ran} 3 A-1$ was differentially regulated in various tissues as well as under the low temperature and SA treatments. In contrast to MsRan3A-6, MsRan3A-6a was found to be more abundant in flowers than in peels (Fig. 3). We propose that MsRan3A-1a and MsRan3A-6a may have different functions than their wild-type counterparts. The exon deletion in MsRan3A-5 was found in the $3^{\prime}$-UTR. The $3^{\prime}$-UTR contains various regulatory elements and plays roles in post-transcriptional regulation of gene expression (Garneau et al. 2007, Keene 2007). Unlike MsRan3A-6, the highest expression of $M s R a n 3 A-5$ was detected in flowers and pulp. These results suggest that MsRan $3 A-5$ and MsRan $3 A-6$ might function differently. Further study is needed, however, to elucidate whether the exon-deletion in the $3^{\prime}$-UTR of MsRan3A-5 has altered its function.

Plants respond to stresses by reprogramming gene expression, thereby giving rise to metabolic alterations. To activate gene expression, environmental signals must be transduced into a nucleus through a series of signal transduction pathways. Nucleo-cytoplasmic partitioning of proteins is proposed as a vital mechanism involved in regulation of plant response to environmental signalling (Merkle 2003, Meier and Somers 2011). These results confirm the importance of Ran, which plays a role in nucleo-cytoplasmic trafficking proteins.

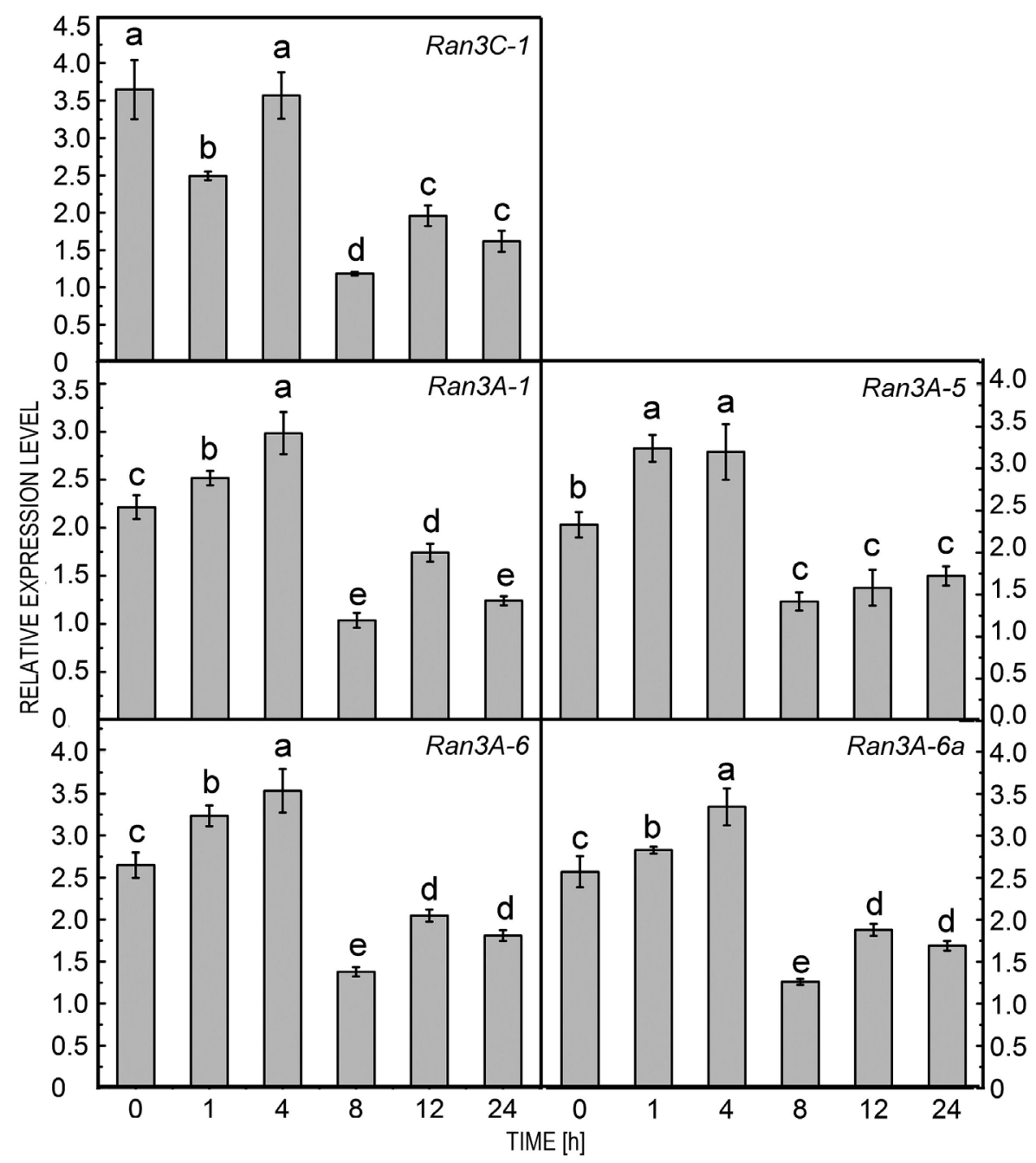

Fig. 6. The effects of a low temperature $\left(8^{\circ} \mathrm{C}\right)$ on expression of MsRan genes in wild banana. The total RNA was extracted from $8{ }^{\circ} \mathrm{C}$ treated shoot cultures at different time points and subjected to real time qPCR analysis. All data were normalized to the expression of $18 \mathrm{~S}$ rRNA. Means \pm SEs, $n=3$. Significant differences were determined by one-way ANOVA $(P<0.05)$ and are indicated by different letters. 
Ran was shown to participate in response to stresses in several plants (Ferreira et al. 2006, Jiang et al. 2007, Li et al. 2007, Xu and Huang 2008, 2010, Yoshimura et al. 2008, Chen et al. 2011, Paul and Kumar 2011). Chen et al. (2011) reported that $4{ }^{\circ} \mathrm{C}$ treatment of rice significantly enhances expression of $O s R A N 2$. However, we found that expressions of MsRan genes increased slightly after 1 and $4 \mathrm{~h}$, then decreased and remained at a low level after the seedlings were treated at $8^{\circ} \mathrm{C}$ for $8 \mathrm{~h}$. When the seedlings were exposed to different temperatures, the abundance of MsRan genes varied. We thus propose that the differences of temperature are responsible for the discrepancy between our results and the previous study. The low expression of MsRan transcripts when treated by $8{ }^{\circ} \mathrm{C}$ for more than $8 \mathrm{~h}$ may be related to growth arrest and injury, which may occur under this temperature (Yang et al. 2012). Our results also indicate that MsRan genes respond to low temperature in various patterns. When the temperature was lower than $8{ }^{\circ} \mathrm{C}$, expressions of $M \operatorname{Ran} 3 A-1$ and MsRan3C-1 were re-enhanced. These could be due to that the banana seedlings adapted their metabolic processes to cope with the cold stress. These results suggest that MsRan genes are involved in a response to low temperature stress.

Salicylic acid plays an important role in modulating plant responses to abiotic and biotic stresses (Senaratna et al. 2000, Ding et al. 2002, Tasgin et al. 2006, Wen et al. 2008, Fu et al. 2011, Saruhan et al. 2012, Mutlu et al. $2013 \mathrm{~b}$.

Salicylic acid treatment increases chilling tolerance of many plants (Mutlu et al. 2013a). Kang et al. (2003a,b)

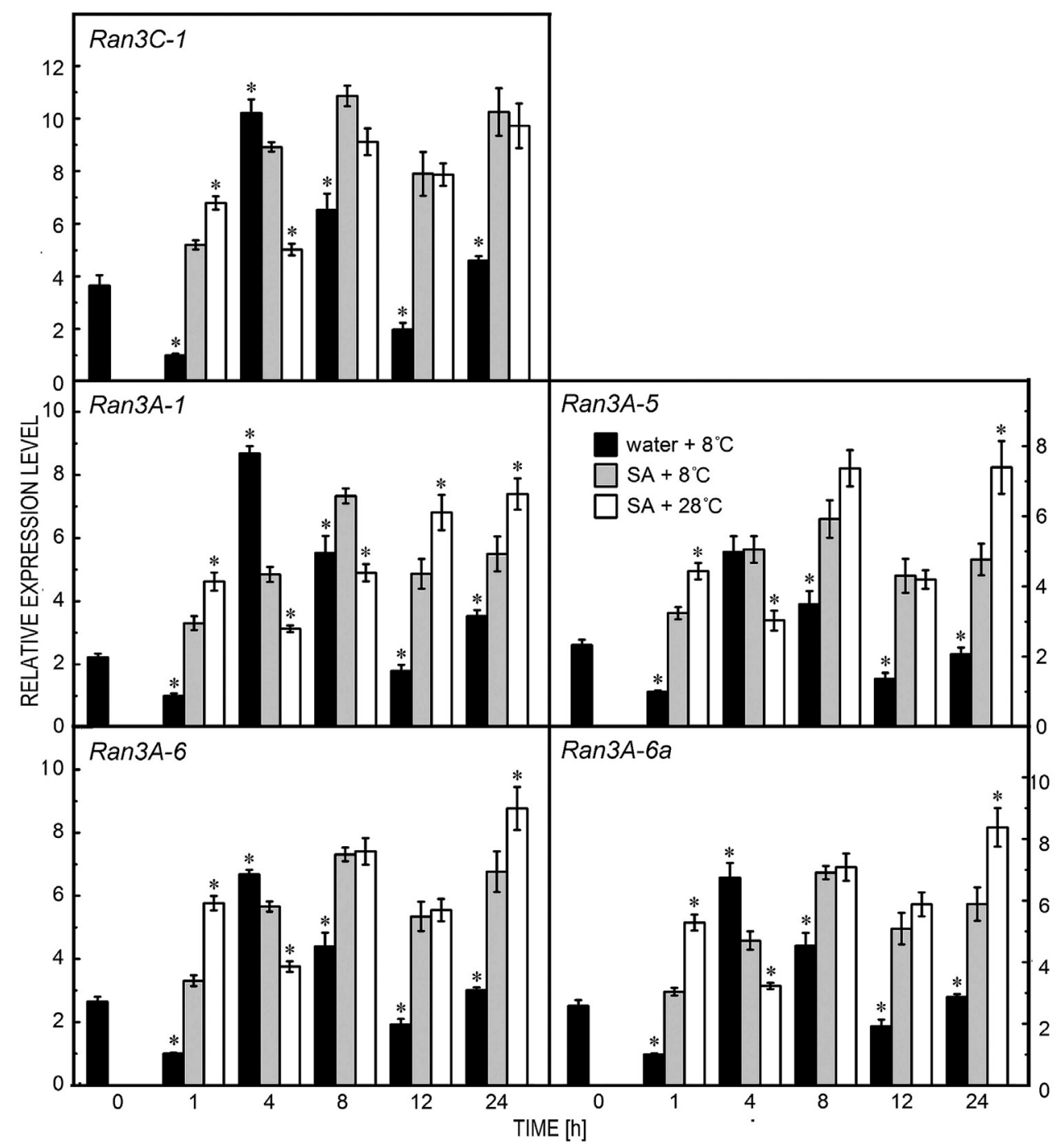

Fig. 7. Expressions of MsRan genes under salicylic acid (SA) treatment in wild banana. Shoot cultures sprayed with $0.5 \mathrm{mM}$ SA or water (control) and incubated under $8{ }^{\circ} \mathrm{C}$. The total RNA was extracted from treated and control plantlets at different time points and subjected to real time quantitative PCR analysis. All data were normalized to the expression of $18 \mathrm{~S}$ rRNA. Means \pm SEs, $n=3$. Significant differences were determined by one-way ANOVA $(P<0.05)$ and indicated by asterisks. 
demonstrated that SA treatment enhances chilling tolerance of banana seedlings. In the present study, MsRan gene expressions in seedlings treated with $0.5 \mathrm{mM}$ SA were significantly enhanced. Especially at the end of the treatment, the MsRan genes were still expressed at a high level. We propose that SA modulates MsRan expression, and a high expression of MsRan genes induced by SA is responsible for an enhanced chilling tolerance of banana.

\section{References}

Ach, R.A., Gruissem, W.: A small nuclear GTP-binding protein from tomato suppresses a Schizosaccharomyces pombe cellcycle mutant. - Proc. nat. Acad. Sci. USA 91: 5863-5867, 1994.

Chen, N., Xu, Y., Wang, X., Du, C., Du, J., Yuan, M., Xu, Z., Chong, K.: OsRAN2, essential for mitosis, enhances cold tolerance in rice by promoting export of intranuclear tubulin and maintaining cell division under cold stress. - Plant Cell Environ. 34: 52-64, 2011.

Ciciarello, M., Mangiacasale, R., Lavia, P.: Spatial control of mitosis by the GTPase Ran. - Cell. mol. Life Sci. 64: 18911914, 2007.

Clarke, P.R., Zhang, C.: Spatial and temporal coordination of mitosis by Ran GTPase. - Nat. Rev. mol. cell. Biol. 9: 46477, 2008.

D'Hont, A., Denoeud, F., Aury, J.M., Baurens, F.C., Carreel, F., Garsmeur, O., Noel, B., Bocs, S., Droc, G., Rouard, M., Da Silva, C., Jabbari, K., Cardi, C., Poulain, J., Souquet, M., Labadie, K., Jourda, C., Lengelle, J., Rodier-Goud, M., Alberti, A., Bernard, M., Correa, M., Ayyampalayam, S., McKain, M.R., Leebens-Mack, J., Burgess, D., Freeling, M., Mbeguie, A.M.D., Chabannes, M., Wicker, T., Panaud, O., Barbosa, J., Hribova, E., Heslop-Harrison, P., Habas, R., Rivallan, R., Francois, P., Poiron, C., Kilian, A., Burthia, D., Jenny, C., Bakry, F., Brown, S., Guignon, V., Kema, G., Dita, M., Waalwijk, C., Joseph, S., Dievart, A., Jaillon, O., Leclercq, J., Argout, X., Lyons, E., Almeida, A., Jeridi, M., Dolezel, J., Roux, N., Risterucci, A.M., Weissenbach, J., Ruiz, M., Glaszmann, J.C., Quetier, F., Yahiaoui, N., Wincker, P.: The banana (Musa acuminata) genome and the evolution of monocotyledonous plants. - Nature 488: 213217, 2012.

Dallol, A., Hesson, L.B., Matallanas, D., Cooper, W.N., O'Neill, E., Maher, E.R., Kolch, W., Latif, F.: RAN GTPase is a RASSF1A effector involved in controlling microtubule organization. - Curr. Biol. 19: 1227-1232, 2009.

Ding, C.K., Wang, C.Y., Gross, K.C., Smith, D.L.: Jasmonate and salicylate induce the expression of pathogenesisrelated-protein genes and increase resistance to chilling injury in tomato fruit. - Planta 214: 895-901, 2002.

Fang, Z., Lai, C., Zhang, Y., Lai, Z.: Molecular cloning, structural and expression profiling of DlRan genes during somatic embryogenesis in Dimocarpus longan Lour. SpringerPlus 5: 181, 2016.

Fang, Z.Z., Zhang, Y.L., Lai, C.C., Lai, Z.X.: Developmental regulation of Ran 3'untranslated region during somatic embryogenesis in Dimocarpus longan Lour. - Sci. Hort. 176: 297-302, 2014.
In conclusion, six MsRan transcripts including three alternatively spliced transcripts were isolated from wild banana and bioinformatically characterized. The high similarity of these sequences to other plant Ran sequences suggests the former are orthologs. The MsRan genes were differentially regulated in various tissues, and they were involved in responses to the low temperature stress. Also, SA significantly enhanced expression of the MsRan genes.

Ferreira, S., Hjernø, K., Larsen, M., Wingsle, G., Larsen, P., Fey, S., Roepstorff, P., Salomé Pais, M.: Proteome profiling of Populus euphratica Oliv. upon heat stress. - Ann. Bot. 98: 361-377, 2006.

Fu, Z., Zhang, Z., Liu, Z., Hu, X., Xu, P.: The effects of abiotic stresses on the NADP-dependent malic enzyme in the leaves of the hexaploid wheat. - Biol. Plant. 55: 196-200, 2011.

Garneau, N.L., Wilusz, J., Wilusz, C.J.: The highways and byways of mRNA decay. - Nat. Rev. mol. cell. Biol. 8: 11326, 2007.

Haizel, T., Merkle, T., Pay, A., Fejes, E., Nagy, F.: Characterization of proteins that interact with the GTPbound form of the regulatory GTPase Ran in Arabidopsis. Plant J. 11: 93-103, 1997.

Jiang, Y., Yang, B., Harris, N.S., Deyholos, M.K.: Comparative proteomic analysis of $\mathrm{NaCl}$ stress-responsive proteins in Arabidopsis roots. - J. exp. Bot. 58: 3591-3607, 2007.

Kang, G., Duan, Z., Wang, Z., Sun, G.: Effect of salicylic acid on increasing the cold-tolerance of banana seedlings. - Plant Physiol. Commun. 39: 122-124, 2003 a.

Kang, G., Wang, C., Sun, G., Wang, Z.: Salicylic acid changes activities of $\mathrm{H}_{2} \mathrm{O}_{2}$-metabolizing enzymes and increases the chilling tolerance of banana seedlings. - Environ. exp. Bot. 50: 9-15, 2003b.

Keene, J.D.: RNA regulons: coordination of post-transcriptional events. - Nat. Rev. Genet. 8: 533-543, 2007.

Lai, Z., Chen, Y., Lin, Y., Zhao, Q., Chen, Y.: Discovery and taxonomy of wild banana (Musa spp., AA Group) in Fuzhou. - Subtrop. Agr. Res. 3: 1-5, 2007.

Lai, Z., Chen, Y., Lin, Y., Zhao, Q., Chen, Y., Zhang, Z.: Investigation of basic biological characteristics of wild banana (Musa spp., AB Group) in Sanming City. - Subtrop. Agr. Res. 2: 241-244, 2006.

Lareau, L.F., Green, R.E., Bhatnagar, R.S., Brenner, S.E.: The evolving roles of alternative splicing. - Curr. Opin. Struct. Biol. 14: 273-282, 2004.

Lee, Y., Kim, M.H., Kim, S.K., Kim, S.H.: Phytochromemediated differential gene expression of plant Ran/TC4 small G-proteins. - Planta 228: 215-224, 2008.

Li, K., Xu, C., Zhang, K., Yang, A., Zhang, J.: Proteomic analysis of roots growth and metabolic changes under phosphorus deficit in maize (Zea mays L.) plants. Proteomics 7: 1501-1512, 2007.

Li, P., Yu, X., Ge, K., Melamed, J., Roeder, R.G., Wang, Z.: Heterogeneous expression and functions of androgen receptor co-factors in primary prostate cancer. - Amer. J. Pathol. 161: 1467-1474, 2002. 
Liu, C., Takahashi, M., Li, Y., Dillon, T.J., Kaech, S., Stork, P.J.S.: The interaction of Epac1 and Ran promotes Rap1 activation at the nuclear envelope. - Mol. Cell. Biol. 30: 3956-3969, 2010.

Lü, S., Fan, Y., Jin, C.: Overexpression of a Ran GTPase homologous gene, FaRan from tall fescue, in transgenic Arabidopsis. - Biol. Plant. 55: 331-334, 2011.

Mastrangelo, A.M., Marone, D., Laidò, G., De Leonardis, A.M., De Vita, P.: Alternative splicing: enhancing ability to cope with stress via transcriptome plasticity. - Plant Sci. 185-186: 40-49, 2012.

Meier, I., Somers, D.E.: Regulation of nucleocytoplasmic trafficking in plants. - Curr. Opin. Plant Biol. 14: 538-546, 2011.

Merkle, T.: Nucleo-cytoplasmic partitioning of proteins in plants: implications for the regulation of environmental and developmental signalling. - Curr. Genet. 44: 231-260, 2003.

Miché, L., Battistoni, F., Gemmer, S., Belghazi, M., ReinholdHurek, B.: Upregulation of jasmonate-inducible defense proteins and differential colonization of roots of Oryza sativa cultivars with the endophyte Azoarcus sp. - Mol. Plant Microbe Interact. 19: 502-511, 2006.

Mutlu, S., Karadağoğlu, Ö., Atici, Ö., Nalbantoğlu, B.: Protective role of salicylic acid applied before cold stress on antioxidative system and protein patterns in barley apoplast. - Biol. Plant. 57: 507-513, 2013a.

Mutlu, S., Karadağoğlu, Ö., Atici, Ö., Taşğin, E., Nalbantoğlu, B.: Time-dependent effect of salicylic acid on alleviating cold damage in two barley cultivars differing in cold tolerance. - Turk. J. Bot. 37: 343-349, 2013 b.

Paul, A., Kumar, S.: Responses to winter dormancy, temperature, and plant hormones share gene networks. Funct. Integr. Genomics 11: 659-664, 2011.

Saruhan, N., Saglam, A., Kadioglu, A.: Salicylic acid pretreatment induces drought tolerance and delays leaf rolling by inducing antioxidant systems in maize genotypes. - Acta Physiol. Plant. 34: 97-106, 2012.

Senaratna, T., Touchell, D., Bunn, E., Dixon, K.: Acetyl salicylic acid (aspirin) and salicylic acid induce multiple stress tolerance in bean and tomato plants. - Plant Growth Regul. 30: 157-161, 2000.

Stamm, S., Ben-Ari, S., Rafalska, I., Tang, Y., Zhang, Z., Toiber, D., Thanaraj, T.A., Soreq, H.: Function of alternative splicing. - Gene 344: 1-20, 2005.

Tasgin, E., Atici, O., Nalbantoglu, B., Popova, L.P.: Effects of salicylic acid and cold treatments on protein levels and on the activities of antioxidant enzymes in the apoplast of winter wheat leaves. - Phytochemistry 67: 710-715, 2006.

Vandesompele, J., Preter, K.D., Pattyn, F., Poppe, B., Roy, N.V., Paepe, A.D., Speleman, F.: Accurate normalization of real-time quantitative RT-PCR data by geometric averaging of multiple internal control genes. - Genome Biol. 3: 503$515,2002$.

Vernoud, V., Horton, A.C., Yang, Z., Nielsen, E.: Analysis of the small GTPase gene superfamily of Arabidopsis. - Plant
Physiol. 131: 1191-1208, 2003.

Wang, X., Han, Y., Chen, C.B., Chong, K., Xu, Z.H.: Wheat RAN1 affects microtubules integrity and nucleocytoplasmic transport in fission yeast system. - Acta bot. sin. 46: 940947, 2004.

Wang, X., Xu, Y., Han, Y., Bao, S., Du, J., Yuan, M., Xu, Z., Chong, K.: Overexpression of RAN1 in rice and Arabidopsis alters primordial meristem, mitotic progress, and sensitivity to auxin. - Plant Physiol. 140: 91-101, 2006.

Wen, P.F., Chen, J.Y., Wan, S.-B., Kong, W.F., Zhang, P., Wang, W., Zhan, J.C., Pan, Q.H., Huang, W.-D.: Salicylic acid activates phenylalanine ammonia-lyase in grape berry in response to high temperature stress. - Plant Growth Regul. 55: 1-10, 2008.

$\mathrm{Xu}, \mathrm{C}$., Huang, B.: Root proteomic responses to heat stress in two Agrostis grass species contrasting in heat tolerance. - J exp. Bot. 59: 4183-4194, 2008.

$\mathrm{Xu}, \mathrm{C}$., Huang, B.: Differential proteomic response to heat stress in thermal Agrostis scabra and heat-sensitive Agrostis stolonifera. - Physiol.Plant. 139: 192-204, 2010.

Yang, Q.S., Wu, J.H., Li, C.Y., Wei, Y.R., Sheng, O., Hu, C.H., Kuang, R.B., Huang, Y.H., Peng, X.X., McCardle, J.A., Chen, W., Yang, Y., Rose, J.K.C., Zhang, S., Yi, G.J.: Quantitative proteomic analysis reveals that antioxidation mechanisms contribute to cold tolerance in plantain (Musa paradisiaca L.; ABB Group) seedlings. - Mol. Cell Proteomics 11: 1853-1869, 2012.

Yano, A., Kodama, Y., Koike, A., Shinya, T., Kim, H.-J., Matsumoto, M., Ogita, S., Wada, Y., Ohad, N.I.R., Sano, $\mathrm{H}$.: Interaction between methyl $\mathrm{CpG}$-binding protein and Ran GTPase during cell division in tobacco cultured cells. Ann. Bot. 98: 1179-1187, 2006.

Yoshimura, K., Masuda, A., Kuwano, M., Yokota, A., Akashi, K.: Programmed proteome response for drought avoidance/tolerance in the root of a $\mathrm{C}_{3}$ xerophyte (wild watermelon) under water deficits. - Plant Cell Physiol. 49: 226-241, 2008

Zang, A., Xu, X., Neill, S., Cai, W.: Overexpression of OsRAN2 in rice and Arabidopsis renders transgenic plants hypersensitive to salinity and osmotic stress. - J. exp. Bot. 61: 777-789, 2010.

Zhang, M.X., Lai, Z.X., He, S.L., Huang, Y.J., Lin, Y.L., Wu, J.S.: Development of a transgenic acceptor system for banana. - J. Fujian Agr. Forest. Univ. 35: 509-514, 2006.

Zhang, Y.L., Fang, Z.Z., Lai, Z.X.: Cloning and bioinformatics analysis of DNA sequence of Ran family genes in wild banana (Musa spp.AB group) from Sanming. - Chin. J. trop. Crops 35: 890-896, 2014.

Zhang, Y.L., Fang, Z.Z., Lai, Z.X.: Cloning and expression analysis of Ran gene in different tissues and under low temperature stress in Sanming yesheng jiao (Musa itinerans). - J. Fruit Sci. 32: 26-36, 2015 a.

Zhang, Y.L., Fang, Z.Z., Lai, Z.X.: Genome-wide analysis of the Ran gene family in banana (Musa acuminata). - Acta agricult. Univ. Jiangxiensis 37: 157-162, 2015b. 